\title{
Genetical Studies of Serum Resistance in Escherichia coli
}

\author{
By P. W. TAYLOR \\ Department of Medicine, Charing Cross Hospital Medical School, \\ London W6 8RF
}

(Received 26 September 1974; revised 4 February 1975)

\section{SUMMARY}

One induced and one spontaneous serum-resistant mutant were derived from smooth serum-sensitive Escherichia coli strains. There was little difference in the yield or the O-side-chain-sugar to core-sugar ratio of lipopolysaccharides from the mutants compared with the parental strains. The mutations to serum resistance were not accompanied by increases in either the amount or haemagglutinationinhibiting activity of acidic polysaccharides extracted from the strains.

Two colonially rough forms, designated $17 \mathrm{fa}$ and $17 \mathrm{gb}$, were isolated from an aged culture of serum-resistant mutant 17 . Escherichia coli $17 \mathrm{fa}$ appeared to be a som mutant and was rapidly killed by serum. Escherichia coli $17 \mathrm{gb}$ retained serological O-specificity, and $17 \mathrm{gb}$ lipopolysaccharide contained a full complement of $\mathrm{O}$-side-chains; the strain was killed by serum but only after a delay of $\mathrm{I} h$.

Escherichia coli K-negative O8 donor Hfr59, which was serum-resistant, was crossed with rough serum-sensitive $E$. coli strain $\mathrm{F} 470$ and $\mathrm{his}^{+}$recombinants were selected. The majority of his ${ }^{+}$recombinants inherited a full complement of lipopolysaccharide $\mathrm{O}$-side-chains but were killed by serum after a delay of $\mathrm{I}$ to $2 \mathrm{~h}$.

These results suggest that lipopolysaccharide $\mathrm{O}$-side-chains are responsible for a delay in the killing by normal human serum of smooth $E$. coli strains but that other factors determine full serum resistance. No evidence was found of a role for $\mathrm{K}$-antigens in serum resistance.

\section{INTRODUCTION}

A large number of strains of Gram-negative bacteria are susceptible to the complementmediated lethal action of normal human serum. Serum-resistant strains are encountered, however, and may be frequently isolated from a wide range of infections in man (Roantree \& Rantz, 1960; Fierer, Finley \& Braude, 1972). Although the mechanism of resistance to the serum bactericidal system has yet to be fully defined, it has been suggested that certain surface structures are able to protect the bacterial cell. In Escherichia coli, resistance has been attributed to the amount of lipopolysaccharide associated with the outer membrane (Wardlaw, 1963), to the amount of O-specific side-chain material compared with core material in the lipopolysaccharide (Feingold, 1969) or to the amount and haemagglutinationinhibiting activity of acidic polysaccharide ( $\mathrm{K}$ antigen) associated with the cells (Glynn \& Howard, 1970).

In a previous study from this laboratory it was found that no single proposed mechanism of resistance was able to explain fully the behaviour in normal human serum of 28 smooth strains of $E$. coli isolated from cases of urinary tract infection (Taylor, unpublished). Some of the factors studied were, however, correlated to a certain extent with serum-resistance, suggesting that they might contribute towards resistance in certain strains but not in others. Further comparative studies of wild-type strains differing in serum sensitivity appear unlikely to clarify the precise role of cell surface structures in serum resistance. The variation 
in response to serum as a result of an altered growth environment observed with some strains suggests a possible basis for further studies. The investigation of mutants differing in serum sensitivity from the parental type may also provide an alternative approach to the problem.

Serum-sensitive mutants have been derived from serum-resistant strains by a number of workers (Nelson \& Roantree, 1967; Medearis, Camitta \& Heath, 1968; Muschel \& Larsen, 1970) but, unfortunately, the majority of such mutants are rough or part-rough and differences between these strains cannot be used to explain the behaviour in serum of smooth isolates. An attempt was therefore made to isolate serum-resistant mutants from some of the smooth serum-sensitive $E$. coli strains considered in a previous study (Taylor, unpublished). This report describes the characterization of such mutants and additional genetical studies on serum resistance in $E$. coli.

\section{METHODS}

Bacteria. Escherichia coli LP729 (serogroup O9) and E. coli LP22 I 2 (OI8ac: K ?: $\mathrm{H}_{5}$ ) were isolated from infections of the urinary tract. Escherichia coli $\mathrm{F} 470\left(\mathrm{~F}^{-}\right.$, his, met, pro, str-r) and $E$. coli $\mathrm{F} 576$ are rough strains with complete $\mathrm{R}_{\mathrm{I}}$ and $\mathrm{R} 2$ lipopolysaccharide core structures respectively (Schmidt, Jann \& Jann, 1969). Escherichia coli Hfr59 (ilv, str-s) is a Knegative strain derived from $E$. coli $\mathrm{E} 56 \mathrm{~b}\left(\mathrm{O} 8: \mathrm{K} 27_{2}: \mathrm{H}^{-}\right)$by Schmidt (1969); Hfr59 transfers the his-linked O8 gene as an early marker. Strains F470, F576 and Hfr59 were kindly provided by Dr G. Schmidt.

Bacteriophages. Bacterial strains were characterized using phages actively lytic against various rough forms of $E$. coli (Schmidt et al. 1969; Rapin \& Kalckar, 1971). Phages FO, Br2, Brio, FpI and 6SR were obtained from Dr G. Schmidt; T3 and T4 were a gift from Dr R. Wilkinson. Phages were propagated on suitable bacterial host strains according to Hershey, Kalmanson \& Bronfenbrenner (1943). Bacterial sensitivity was determined by applying drops of phage $\left(10^{8}\right.$ plaque-forming units $\left./ \mathrm{ml}\right)$ on to surface-inoculated nutrient agar plates.

Estimation of serum sensitivity. This technique has been described in detail by Taylor, Roberts \& Gower (1972). Briefly, I $\mathrm{ml}$ of tris- $\mathrm{HCl} \mathrm{pH} 8.4$ containing $\mathrm{I} \times 10^{6}$ bacteria in early exponential phase was added to $3 \mathrm{ml}$ of normal human serum. Viable counts were made, using the pour plate technique, at the beginning of the test and after $\mathrm{I}, 2$ and $3 \mathrm{~h}$ incubation at $37^{\circ} \mathrm{C}$. The results were normally categorized into six grades, grade I being the most sensitive and grade 6 the most resistant.

Isolation of serum-resistant mutants. An early exponential-phase nutrient broth (Oxoid No. 2) culture was washed twice in TM buffer (Adelberg, Mandel \& Chen, 1965) and resuspended in $4.5 \mathrm{ml} \mathrm{TM}$ buffer. $N$-methyl- $N^{\prime}$-nitro- $N$-nitrosoguanidine was then added to give a final concentration of $100 \mu \mathrm{g} / \mathrm{ml}$ and the suspension left at room temperature for $30 \mathrm{~min}$. After three washes in $0.9 \%(\mathrm{w} / \mathrm{v}) \mathrm{NaCl}, 20 \mathrm{ml}$ nutrient broth were added and the culture incubated at $37^{\circ} \mathrm{C}$ for $3 \mathrm{~h}$. The culture was then washed in $0.9 \%(\mathrm{w} / \mathrm{v}) \mathrm{NaCl}$ and a suspension prepared in tris- $\mathrm{HCl} \mathrm{pH} 8.4$ containing about $\mathrm{I} \times 10^{8}$ bacteria $/ \mathrm{ml}$. A sample ( $\mathrm{I} \mathrm{ml}$ ) was added to $3 \mathrm{ml}$ normal human serum and the mixture incubated at $37^{\circ} \mathrm{C}$ for $3 \mathrm{~h}$. The suspension was plated on to nutrient agar and surviving colonies examined for resistance to serum by the technique of Taylor et al. (1972). For the isolation of spontaneous mutants, the same procedure was followed without the mutagenizing step.

Mating procedure. The mating procedure of Schmidt, Fromme \& Mayer (1970) was used.

Slide agglutination. O- and R-antisera were prepared according to Schlecht \& Westphal (1967). For slide agglutination tests, O8 (anti-Hfr59), RI (anti-F470) and R2 (anti-F576) 
antisera were diluted $\mathrm{I}: \mathrm{IO}$ in $0.3 \%(\mathrm{w} / \mathrm{v}) \mathrm{NaCl}$ (Schmidt, 1973), to avoid non-specific agglutination of rough forms. Bacteria were also tested for spontaneous agglutination in $0.2 \%(\mathrm{w} / \mathrm{v})$ acriflavine and in $3.5 \%(\mathrm{w} / \mathrm{v}) \mathrm{NaCl}$.

Extraction of polysaccharides. Cultures were cultivated in conical flasks (2.5 l) containing $700 \mathrm{ml}$ nutrient broth at $37^{\circ} \mathrm{C}$ for $16 \mathrm{~h}$ in an orbital incubator ( 120 orbits $/ \mathrm{min}$ ). Two methods, the phenol-water (Westphal \& Jann, 1965) and the warm saline technique (Jann et al. 1970), were used to extract lipopolysaccharides and acidic polysaccharides from washed and dried cells. Acidic polysaccharides were obtained by Cetavlon precipitation according to procedure III of Westphal \& Jann (1965).

Chemical analysis of lipopolysaccharide. For the determination of the neutral sugar composition, $2 \mathrm{mg}$ of lipopolysaccharide were hydrolysed $\left(10{ }^{\circ} \mathrm{C}, 48 \mathrm{~h}\right)$ in sealed tubes containing $2 \mathrm{ml} \mathrm{O} \cdot \mathrm{I} \mathrm{M}-\mathrm{HCl}$. After the addition of the internal standard, xylose, the hydrolysate was neutralized with Amberlite IRA $4 \mathrm{IO}\left(\mathrm{HCO}_{3}^{-}\right)$. Heptose-linked phosphate residues were removed by treatment of the neutral solution with $E$. coli alkaline phosphatase (Sigma) and aldoses were converted to the corresponding alditol acetates according to the procedure described by Holme et al. (1968). Alditol acetates were dissolved in $0 \cdot 2 \mathrm{ml}$ chloroform and I $\mu \mathrm{l}$ samples were injected into a Pye Unicam Series I04 gas-liquid chromatograph fitted with $6 \mathrm{~mm} \times 2.7 \mathrm{~m}$ glass columns containing $3 \%$ ECNSS-M on 100 to $120 \mathrm{mesh}$ Gas-Chrom Q (Applied Science Laboratories Incorporated, State College, Pennsylvania, U.S.A.). Separations were obtained isothermally $\left(180^{\circ} \mathrm{C}\right)$ with a nitrogen carrier gas flow rate of $45 \mathrm{ml} / \mathrm{min}$ and peaks were identified by comparison with authentic alditol acetates.

Hexosamine was determined by the method of Strominger, Park \& Thompson (1959) after removal of lipid A. 2-Keto-3-deoxy-octonic acid (KDO) was estimated according to Ellwood (1970).

Serology. The passive haemagglutination technique used was essentially that of Schmidt et al. (1970). The haemagglutination-inhibiting activity of acidic polysaccharide was determined by the technique of Glynn \& Howard (1970).

\section{RESULTS}

An attempt was made to isolate both spontaneous and induced serum-resistant mutants from a large number of smooth, serum-sensitive strains. Most bacteria surviving the initial incubation in serum were as serum-sensitive as the original cultures on subsequent testing, but a small number of survivors of strains LP729 and LP2212 were found to be serum-resistant. The induced mutant from strain LP729 selected for further study was designated 17 ; RM32 is a spontaneous mutant from LP221 2. Both mutants retained the parental O-serotype, cultural and colonial characteristics and reactivity in a wide range of biochemical tests. The mutants have been stored on nutrient agar slopes at $4{ }^{\circ} \mathrm{C}$ for three years, with periodic subculture; no reversion to the parental phenotype has been observed.

\section{Mutant RM32}

Like the parent strain, LP2212, this mutant was resistant to the seven bacteriophages listed in Methods. It was resistant to serum whether the inoculum for the test was taken from an early exponential-phase culture in the usual way, or was taken from the $\mathrm{I} 6 \mathrm{~h}$ mass culture.

There was little difference in the amount of lipopolysaccharide which could be extracted from E. coli $\mathrm{LP22} 2 \mathrm{2}$ and E. coli $\mathrm{RM} 32$ (Table I). A slightly lower titre in passive haemagglutination tests with anti-RI sera was found with lipopolysaccharide from the mutant, but 


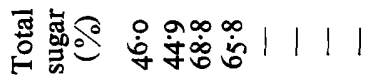

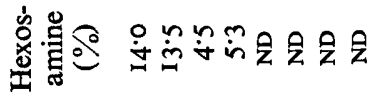

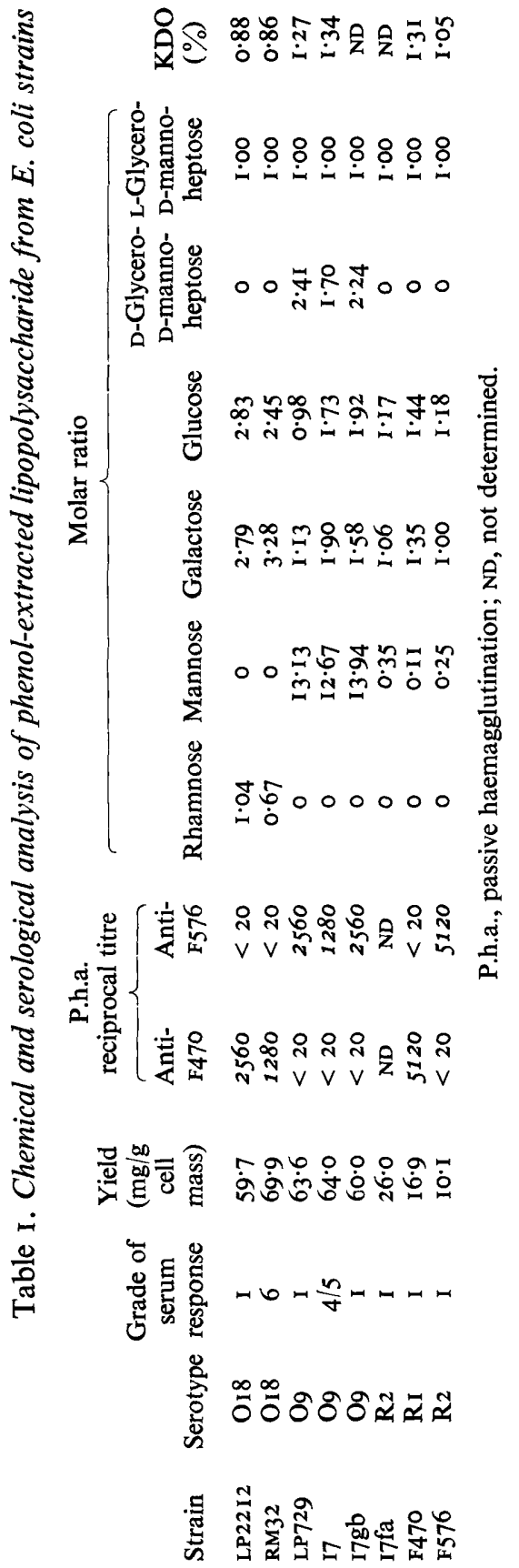


was not reflected in a higher O-side-chain-sugar (rhamnose) to core-sugar (L-glycero-Dmannoheptose) ratio. Indeed, there appeared to be a smaller amount of O-side-chain material in lipopolysaccharide from $E$. coli RM32. The mutation to serum resistance was not accompanied by an increase in the amount of material precipitating with Cetavlon in either phenol-water or warm saline extracts. Acidic polysaccharides from both strains showed no haemagglutination-inhibiting activity.

\section{Mutant 17}

The phage-sensitivity pattern of strain 17 was found to be identical to that of the parent LP729; both strains were lysed by FO and T4 phages. Strain 17 was serum-resistant with an inoculum taken from a $16 \mathrm{~h}$ mass culture.

Little or no difference in the yield, composition or serological behaviour of lipopolysaccharides from strains LP729 and 17 could be found (Table 1). Degraded polysaccharides obtained from the lipopolysaccharide of $E$. coli 17 by hydrolysis ( $100{ }^{\circ} \mathrm{C}, 90 \mathrm{~min}$ ) in I \% acetic acid were fractionated on Sephadex G-50 according to the method described by Schmidt et al. (1969). The elution profile obtained was identical to that found (Taylor, unpublished) for polysaccharides from the parent strain LP729; this indicates a similar degree of core substitution in both strains. No increase was found in either the yield or haemagglutination-inhibiting activity of acidic polysaccharide from the mutant compared with the parent strain.

\section{Rough mutants derived from $E$. coli 17}

It is generally accepted that the loss of the O-side-chain moiety of the lipopolysaccharide leads to a marked increase in serum sensitivity. As the mutation to serum resistance in $E$. coli LP729 did not result in any detectable alteration in the composition of the lipopolysaccharide, it was considered of interest to isolate colonially rough mutants from the serumresistant mutant 17 in order to determine their response to serum. Therefore, E. coli 17 was incubated at $37^{\circ} \mathrm{C}$ in nutrient broth and periodically subcultured on to nutrient agar plates. After 2 to 3 weeks, a number of rough colonies were evident; two such colonial variants, designated $E$. coli $17 \mathrm{gb}$ and $E$. coli $\mathrm{I} 7 \mathrm{fa}$, were selected for further study. Both rough variants were sensitive to serum. However, whereas strain I7fa was rapidly killed, strain $17 \mathrm{gb}$ was killed only after a delay of $\mathrm{I} h$; the response to serum of the latter strain was indistinguishable from that of E. coli LP729.

In contrast to both $E$. coli LP729 and I7, strains $17 \mathrm{gb}$ and $17 \mathrm{fa}$ spontaneously agglutinated in acriflavine solution. Strain $17 \mathrm{gb}$ differed from $17 \mathrm{fa}$, however, in being agglutinated by $\mathrm{O} 9$ antisera and by retaining the parental phage sensitivity pattern. Escherichia coli I7fa was lysed by FO phage, which is considered to absorb only to $E$. coli strains with the complete R2 core (Schmidt et al. 1969, 1970), and also by 6SR, T3 and T4, but was resistant to other phages ( $\mathrm{Br2}$, Brio and FpI) which lyse $E$. coli $\mathrm{R2}$ mutants such as $\mathrm{F} 576$. This resistance may be due to events occurring after phage absorption.

The neutral sugar composition of lipopolysaccharide from the mutants was determined by gas-liquid chromatography of alditol acetates (Table I). Although E. coli $17 \mathrm{gb}$ displayed rough characteristics, there appeared to be no loss of O-side-chain material from the lipopolysaccharide of this strain. The composition of the lipopolysaccharide from $E$. coli i7fa was very similar to that from $E$. coli F576.

An attempt was made to determine whether or not lipopolysaccharide from I7fa contained the complete $\mathrm{R} 2$ core structure. If $17 \mathrm{fa}$ produces a complete core, and carries a hislinked som defect, it will be able to synthesize and attach the O-side-chain polysaccharide specified by a functional som gene cluster transferred from a smooth $E$. coli donor. Therefore, 
a his mutant of $17 \mathrm{fa}$ (his, str-r) was isolated (Clowes \& Hayes, 1968), crossed with the E. coli donor strain Hfr59 (O8:K27-, his ${ }^{+}$, str-s) and his ${ }^{+}$, str-r recombinants were selected on minimal agar containing streptomycin. Sixty-three of 76 recombinants were strongly agglutinated by anti-O8 serum, indicating the presence of lipopolysaccharide containing O8-specific structures. They were also agglutinated, however, by anti-R2 serum and were therefore not fully smooth. The remaining 13 recombinants were agglutinated only by anti-R2 serum, indicating that they inherited the his cluster but not the som locus.

Anti-R2 serum was absorbed with heat-killed suspensions of strains $F 576$ and $17 f a$ according to Schmidt et al. (1970) and used in passive haemagglutination tests against sheep red cells coated with $\mathrm{F}_{576} 6$ lipopolysaccharide. Both suspensions removed all anti-R2 haemagglutinins from anti-R2 serum.

These results are consistent with the proposition that lipopolysaccharide from $E$. coli $17 \mathrm{fa}$ contains the complete $\mathrm{R} 2$ core structure and lacks the $\mathrm{O}$-side-chain moiety. A sugar resembling D-glycero-D-mannoheptose was found in hydrolysates of lipopolysaccharide from strains LP729, I7 and I7gb, but was absent from I7fa lipopolysaccharide (Table I). It therefore appears that, in agreement with previous results (Taylor, unpublished), this sugar is confined to the O-side-chain moiety of lipopolysaccharide from E. coli LP729.

Serum sensitivity of recombinants from the cross of E. coli Hfr59 to E. coli $\mathrm{F} 470$

During the course of this work it was found that E. coli Hfr59 was resistant to normal human serum (grade 6). It therefore provided an opportunity to study the effect of O-sidechains on serum resistance by transferring the som locus from this strain to a suitable serumsensitive rough recipient. The reactivity of the majority of recombinants from the Hfr $59 \times$ ${ }_{17 f a}$ cross in both anti-O8 and anti-R2 serum suggests that a high proportion of the R2 core stubs are not substituted by $\mathrm{O}$-side-chains. It was therefore decided to use $E$. coli $\mathrm{F} 470$ (his, met, pro, str-r) as a recipient; lipopolysaccharide from both $E$. coli $\mathrm{Hfr} 59$ and $E$. coli $\mathrm{F} 470$ possesses the RI core structure.

Escherichia coli $\mathbf{F} 470$ was crossed with the donor strain $\mathrm{Hfr} 59$ and his ${ }^{+}$, str-r recombinants were selected. Of I 40 such recombinants, I 2 I $(86.4 \%)$ were agglutinated by anti-O 8 serum and had therefore inherited the his-linked som locus. The majority of recombinants reactive in anti-O8 serum appeared fully smooth and were not agglutinated by anti-RI serum. Three were agglutinated by both anti-O8 and anti-R $\mathrm{I}$ serum. Unlike the donor or recipient, the fully smooth recombinants did not agglutinate in $0.2 \%$ acriflavine. Ten recombinants inherited the his but not the som locus. Neither living nor heat-killed $\left(100{ }^{\circ} \mathrm{C}, \mathrm{I} \mathrm{h}\right)$ cells of the remaining nine recombinants reacted in anti-O8 or in anti-RI serum.

The serum sensitivity of several recombinants was determined and a number of different responses to normal human serum were evident. All but one of the 27 fully-smooth recombinants examined were killed by serum after a lag period of $\mathrm{I}$ to $2 \mathrm{~h}$; none was fully serumresistant. The ten rough recombinants were all as sensitive to serum as the recipient strain F470. The serum sensitivity of the part-rough recombinants fell between that of the smooth and the rough recombinants. Five of the nine recombinants failing to agglutinate in anti-O8 and anti-RI serum gave the response which characterized the smooth recombinants.

The difference in serum sensitivity between the smooth recombinants and the donor strain might be related to the amount of O-side-chain material associated with the lipopolysaccharide. Therefore, lipopolysaccharide was extracted with phenol-water from two fully-smooth recombinants, RecI and Rec7, and for comparison, from the partrough recombinant Rec2I. Lipopolysaccharide was also extracted from Rec55 and Rec 74 in an attempt to explain their non-reactivity in anti-O8 and anti-R I serum. The yield of 
Table 2. Neutral sugar composition of lipopolysaccharides extracted by the phenol-water technique from recombinants of the cross $\mathrm{Hfr} 59 \times \mathbf{F} 470$

\begin{tabular}{|c|c|c|c|c|c|c|c|}
\hline \multirow[b]{3}{*}{ Recombinants } & \multirow{2}{*}{\multicolumn{2}{|c|}{$\begin{array}{l}\text { Agglutination, } \\
\text { in antisera: }\end{array}$}} & \multicolumn{5}{|c|}{ Molar ratios } \\
\hline & & & \multirow[b]{2}{*}{ Mannose } & \multirow[b]{2}{*}{ Galactose } & \multirow[b]{2}{*}{ Glucose } & \multirow{2}{*}{$\begin{array}{l}\text { D-Glycero- } \\
\text { D-manno- } \\
\text { heptose }\end{array}$} & \multirow{2}{*}{$\begin{array}{c}\text { L-Glycero- } \\
\text { D-manno- } \\
\text { heptose }\end{array}$} \\
\hline & 08 & RI & & & & & \\
\hline RecI & + & - & $13 \cdot 35$ & $\mathrm{I} \cdot 98$ & $I \cdot 42$ & $2 \cdot 25$ & I.00 \\
\hline Rec7 & + & - & $16 \cdot 49$ & $2 \cdot 29$ & 1.65 & $2 \cdot 29$ & 1.00 \\
\hline $\operatorname{Rec} 2 \mathrm{I}$ & + & + & $9 \cdot 90$ & $2 \cdot 73$ & 1.58 & $2 \cdot 10$ & 1.00 \\
\hline $\operatorname{Rec} 55$ & - & - & II 996 & 2.01 & $\mathrm{I} \cdot 94$ & $2 \cdot 32$ & $1 \cdot 00$ \\
\hline Rec74 & - & - & $17 \cdot 02$ & $2 \cdot 15$ & $2 \cdot 06$ & $2 \cdot 30$ & 1.00 \\
\hline \multicolumn{8}{|l|}{ Parental strains } \\
\hline Hfr59 & + & - & $16 \cdot 34$ & $2 \cdot 22$ & $I \cdot 83$ & $2 \cdot 14$ & $1 \cdot 00$ \\
\hline F470 & - & + & $0 . \mathrm{II}$ & I.35 & $\mathrm{I} \cdot 44$ & 0 & $1 \cdot 00$ \\
\hline
\end{tabular}

lipopolysaccharide from RecI and Rec 7 was similar to that from the donor strain. The neutral sugar composition of the lipopolysaccharides was determined. The O-side-chain of the lipopolysaccharide from $E$. coli O8 is a mannan (Reske \& Jann, 1972); the ratio of mannose to L-glycero-D-mannoheptose in lipopolysaccharide from the two fully-smooth recombinants was similar to the ratio found in lipopolysaccharide from the donor strain (Table 2). The lowest amount of $\mathrm{O}$-side-chain material was associated with lipopolysaccharide from the part-rough recombinant, Rec2I. The composition of lipopolysaccharide from Rec55 and Rec74 was very similar to that from the fully-smooth recombinants. A sugar resembling D-glycero-D-mannoheptose was associated with lipopolysaccharide from the donor strain and all the recombinants investigated. As this sugar is not a component of the RI core, it is likely to be associated with the $\mathrm{O}$-side-chain moiety in these preparations.

No acidic polysaccharides were obtained by Cetavlon precipitation from extracts of either the donor strain or any of the recombinants.

\section{DISCUSSION}

The results of a previous study (Taylor, unpublished) suggested that serum resistance in certain strains of $E$. coli may be determined by as yet unidentified factors. The immunochemical analysis of serum-resistant mutants undertaken here lends support to this suggestion. The mutation to serum resistance in the two cases studied could not be attributed to any factors currently thought to influence the behaviour of Gram-negative bacteria in. normal serum. Current theories of serum resistance also fail to explain the results of Nelson \& Roantree (1967), who isolated serum-sensitive mutants from serum-resistant strains of Salmonella spp. Although the majority of such mutants were phenotypically rough or part-rough, a small number possessed lipopolysaccharide with an O-side-chain-sugar to core-sugar ratio identical to that found in the parent strains. A similar rough mutant, E. coli $17 \mathrm{gb}$, was found in the present study. Lipopolysaccharide from strain $17 \mathrm{gb}$ had an almost identical neutral sugar composition to lipopolysaccharide from strains LP729 and 17 (Table I). Clearly, the rough characteristics of strain $17 \mathrm{gb}$ cannot be attributed to the loss of the O-side-chain moiety of the lipopolysaccharide. Similar rough forms with serological O-specificity have been described previously (see Luderitz et al. 197I).

Although the presence of the $\mathbf{O}$-side-chain does not in itself determine complete serum resistance, the present study indicates that it is likely to be responsible for the delayed killing 
effect associated with strains LP729 and $17 \mathrm{gb}$. Stability in acriflavine solution and full resistance to serum appear to be determined by additional independent factors. The following tentative scheme is therefore proposed in order to explain the serological, cultural and immunological behaviour of the various mutants of $E$. coli LP729. Almost all the core stubs of LP729 lipopolysaccharide are substituted with O-side-chains, which are responsible for the delay in serum-killing of strain LP729. The stability in acriflavine of this strain is determined by the presence of a cell surface component associated with the O-side-chain moiety. The mutation to serum resistance results in the synthesis and translocation of an additional surface component which determines complete resistance. Strain $17 \mathrm{gb}$, derived from strain 17 , has lost the factors responsible for both acriflavine stability and complete resistance but retains a full complement of $\mathrm{O}$-side-chains. It is therefore agglutinated by acriflavine and is killed by serum after a delay period. Escherichia coli $17 f a$ is completely sensitive to serum and is agglutinated by acriflavine due to an inability to synthesize or translocate $\mathrm{O}$-side-chains, without which the acriflavine stability factor and the serum resistance factor cannot be retained at the cell surface. It is suggested that the proposed factors may be protein in nature. Powerful techniques have recently become available for the investigation of the protein composition of the outer membrane (Schnaitman, 1970; Osborn et al. 1972), and it is therefore now possible to ascertain whether or not changes in membrane protein composition accompany the mutations described in this study. Such investigations are at present being undertaken.

The response to normal human serum of $E$. coli $\mathrm{Hfr} 59$ demonstrated that the presence of a $\mathrm{K}$-antigen is not essential for serum resistance. The serum resistance of $E$. coli Hfr59 provided an opportunity to determine directly the effect of acquisition of the som locus on serum sensitivity. Escherichia coli $\mathbf{I} 7 \mathrm{fa}$, although possessing a complete lipopolysaccharide core, was not a suitable recipient because no fully-smooth his ${ }^{+}$recombinants were found when this strain was crossed with $E$. coli $\mathrm{Hfr} 59$. Similar part-rough his $^{+}$recombinants were found by Jones, Koeltzow \& Stocker (1972) when Hfr59 was crossed with the E. coli KI 2 strain X971. Schmidt (1973) found that some smooth his ${ }^{+}$recombinants from crosses between Hfr 59 and the E. coli KI 2 strain 2578 segregated partly-rough forms which retained the $h i{ }^{+}$character. He suggested that smooth recombinants were partial diploids for donor genes determining lipopolysaccharide synthesis; loss of these genes resulted in the partrough phenotype. Escherichia coli $\chi 97 \mathrm{I}$ and $E$. coli $\mathrm{I} 7 \mathrm{fa}$ may not maintain partial diploidy as readily as the recipient used by Schmidt (1973).

The majority of $\mathrm{his}^{+}$recombinants from the cross between $\mathrm{Hfr} 59$ and F470 retained the fully-smooth phenotype after subculture. Twenty-six of the 27 fully-smooth recombinants examined were killed by serum after a delay of $\mathrm{I}$ to $2 \mathrm{~h}$, indicating that although inheritance of a full complement of O8-side-chains results in a partial increase in serum resistance, it does not determine the complete resistance characteristic of the donor strain. The remaining fully-smooth recombinant was only slightly less resistant that the donor, suggesting that it may have inherited genes distal to his which influence serum sensitivity. Therefore, the results of both the mating between $E$. coli $\mathrm{Hfr} 59$ and $E$. coli $\mathrm{F} 470$ and the analysis of mutants derived from $E$. coli LP729, support the proposition that lipopolysaccharide O-side-chains may be directly responsible for a delay in the serum-killing effect, but not for serum resistance. In addition, the part-rough recombinants appeared to be intermediate in sensitivity between the fully-smooth recombinants and the recombinants which had inherited the his cluster but not the som locus.

Somewhat surprisingly, a number of recombinants were not agglutinated by anti-O8 or anti-RI sera but were morphologically indistinguishable from the fully-smooth 
recombinants. Lipopolysaccharide from two of these recombinants contained substantial amounts of mannose, the major component of the O-side-chain (Table 2). The basis of the 08-inagglutinability is currently under investigation.

Also unexpected was the finding that, unlike both parent strains, all smooth recombinants from the cross between Hfr59 and F470 were stable in acriflavine solution. This observation could be explained, however, on the basis of the scheme proposed for the various mutants of $E$. coli LP729. Thus, $E$. coli Hfr59 lacks the proposed acriflavine stability factor, and $E$. coli $\mathrm{F} 470$ has the capacity to synthesize it but is unable to attach it due to lack of O-side-chains. Inheritance of the som locus would enable recombinants both to synthesize and attach this surface component.

I thank Dr G. Schmidt and Dr R. Wilkinson for gifts of bacterial strains and bacteriophages. Antisera were produced with the help of Mr B. Kinchington. This work was supported by grants from the Clinical Research Committee of Charing Cross Hospital and the Dan Mason Research Fund.

\section{REFERENCES}

Adelberg, E. A., Mandel, M. \& Chen, G. C. C. (1965). Optimal conditions for mutagenesis by $N$-methyl$N^{\prime}$-nitro- $N$-nitrosoguanidine in Escherichia coli $\mathrm{K} 12$. Biochemical and Biophysical Research Communications $18,788-795$.

Clowes, R. C. \& Hayes, W. (1968). Experiments in Microbial Genetics. Oxford: Blackwell Scientific Publications.

Ellwood, D. C. (1970). The distribution of 2-keto-3-deoxy-octonic acid in bacterial walls. Journal of General Microbiology 60, 373-380.

FEINGold, D. S. (1969). The serum bactericidal reaction. IV. Phenotypic conversion of Escherichia coli from serum-resistance to serum-sensitivity by diphenylamine. Journal of Infectious Diseases 120, 437444 .

FiERER, J., Finley, F. \& BraUde, A. I. (1972). A plaque assay on agar for detection of Gram-negative bacilli sensitive to complement. Journal of Immunology 109, I I 56-1 158.

Glynn, A. A. \& HowARD, C. J. (1970). The sensitivity to complement of strains of Escherichia coli related to their $\mathrm{K}$ antigens. Immunology $\mathrm{I8}, 33 \mathrm{I}-346$.

Hershey, A. D., Kalmanson, C. \& Bronfenbrenner, J. (1943). Quantitative methods in the study of the phage-antiphage reaction. Journal of Immunology 46, 267-28o.

Holme, T., Lindberg, A. A., Garegg, P. J. \& ONN, T. (I968). Chemical composition of cell wall polysaccharide of rough mutants of Salmonella typhimurium. Journal of General Microbiology 52, 45-54.

JANN, B., JANN, K., SCHMIDT, G., ØRSKOV, I. \& ØRSKOV, F. (1970). Immunochemical studies of polysaccharide surface antigens of Escherichia coli OI00: K ?(B):H2. European Journal of Biochemistry 15, 29-39.

Jones, R. T., Koeltzow, D. E. \& STOCKer, B. A. D. (1972). Genetic transfer of Salmonella typhimurium and Escherichia coli lipopolysaccharide antigens to Escherichia coli $\mathrm{K}-12$. Journal of Bacteriology $11 \mathrm{r}, 758$ 770.

Luderitz, O., Westphal, O., Staub, A. M. \& Nikaido, H. (I971). Isolation and chemical and immunological characterization of bacterial lipopolysaccharides. In Microbial Toxins, vol. 4, pp. 145-233. Edited by G. Weinbaum, S. Kadis and S. J. Ajl. London: Academic Press.

Medearis, D. N., Camitta, B. M. \& Heath, E. C. (1968). Cell wall composition and virulence in Escherichia coli. Journal of Experimental Medicine 128, 399-414.

MuSCHEL, L. H. \& LARSEN, L. J. (I970). The sensitivity of smooth and rough Gram-negative bacteria to the immune bactericidal reaction. Proceedings of the Society for Experimental Biology and Medicine r33, $345-348$.

Nelson, B. W. \& Roantree, R. J. (1967). Analyses of lipopolysaccharides extracted from penicillinresistant, serum-sensitive Salmonella mutants. Journal of General Microbiology 48, I 79-I 88.

Osborn, M. J., Gander, J. E., Parisi, E. \& Carson, J. (1972). Mechanism of assembly of the outer membrane of Salmonella typhimurium. Isolation and characterization of cytoplasmic and outer membrane. Journal of Biological Chemistry 247, 3962-3972. 
Rapin, A. M.C. \& KalcKar, H. M. (197I). The relation of bacteriophage attachment to lipopolysaccharide. In Microbial Toxins, vol. 4, pp. 267-303. Edited by G. Weinbaum, S. Kadis and S. J. Ajl. London: Academic Press.

RESKE, K. \& JANN, K. (1972). The O8 antigen of Escherichia coli: structure of the polysaccharide chain. European Journal of Biochemistry 31, 320-328.

ROANTREE, R. J. \& RANTZ, L. A. (1960). A study of the relationship of the normal bactericidal activity of human serum to bacterial infection. Journal of Clinical Investigation 39, 72-8I.

Schlecht, S. \& WestPhal, O. (1967). Über die Herstellung von Antiseren gegen die somatischen (O-) Antigene von Salmonellen. I. Mitteilung: Untersuchungen über Aggluntinintiter. Zentralblatt für Bakteriologie, Parasitenkunde, Infektionskrankheiten und Hygiene (Abteilung I) 204, 335-355.

SCHмIDT, G. (1969). Konjugation bei $E$. coli $\mathrm{O} 8: \mathrm{K} 27: \mathrm{H}-$. Zentralblatt für Bakteriologie, Parasitenkunde, Infektionskrankheiten und Hygiene (Abteilung I) 21I, 335-344.

SCHмIDT, G. (1973). Genetical studies on the lipopolysaccharide structure of Escherichia coli K12. Journal of General Microbiology 77, I5 I-160.

SCHMidT, G., Fromme, I. \& MAYER, H. (1970). Immunochemical studies on core lipopolysaccharides of Enterobacteriaceae of different genera. European Journal of Biochemistry 14, 357-366.

SCHMIDT, G., JANN, B. \& JANN, K. (1969). Immunochemistry of R lipopolysaccharide of Escherichia coli. Different core regions in the lipopolysaccharides of O group 8. European Journal of Biochemistry Io, 5OI-5IO.

SchNaItMan, C. A. (1970). Examination of the protein composition of the cell envelope of Escherichia coli by polyacrylamide gel electrophoresis. Journal of Bacteriology ro4, 882-889.

Strominger, J. L., Park, J. T. \& Thompson, R. E. (1959). Composition of the cell wall of Staphylococcus aureus: its relation to the mechanism of action of penicillin. Journal of Biological Chemistry 234, 32633268.

TAYLOR, P. W., RoberTs, A. P. \& Gower, P. E. (1972). Evaluation of a technique for the estimation of serum bactericidal activity against Gram-negative organisms. Medical Laboratory Technology 29, 272279.

WARDLAW, A. C. (1963). The complement-dependent bacteriolytic activity of normal human serum. II. Cell wall composition of sensitive and resistant strains. Canadian Journal of Microbiology 9, 41-52.

WeSTPHAL, O. \& JANN, K. (1965). Bacterial lipopolysaccharides: extraction with phenol-water and further applications of the procedure. In Methods in Carbohydrate Chemistry, vol. 5, pp. 83-9I. Edited by R. L. Whistler. London: Academic Press. 